\title{
United We Stand - A Letter During The COVID-19 Pandemic
}

RAKSHA K. BHAT, MD, PGDMLE, PGDHHM

rakshakbhat@gmail.com

Dear Senior Doctors,

In most of the hospitals while the administration claims to run short of ideas to deal with Corona Virus Disease (CoVID) pandemic, funds to dutifully give its employees their deserved salaries \& much required personal protective equipment. A certain group of senior doctors who for whatever reasons want to contribute to the running of the hospital or want to be in good terms with the administrators come up with ideas like,

"Let's post the residents in the ICUs and fever clinics"

"CoVID Management is no rocket science, most of the patients are stable, one nurse and one resident to man the ward should do"

"N95 masks can be given only when confirmed positive cases are there"

"Cloth masks should be ok in OPDs"

"We can give them 32 hours duties; we have done it before let them do it too"

"Let the residents sleep in the changing rooms"

"25-30\% pay cut should be ok"

"We can let go off our incentives"

"Hydroxychloroquine prophylaxis can be given to the senior consultants on priority"

"We consultants can work based on staggering duties"

Within the doctor fraternity itself there has always been division of labour, employee priorities and income. Hard to believe but this is the truth.

*Address correspondence to: Raksha K Bhat. MD, PGDMLE, PGDHHM. Central Laboratory, St.Martha's Hospital Bengaluru-560001. India. E-mail: rakshakbhat@gmail.com

+To cite this article: Raksha K Bhat "United We Stand - A Letter During The COVID-19 Pandemic" The Journal of Healthcare Ethics \& Administration 6, no. 1 (Spring/Summer 2020): 24-25, https://doi.org/10.22461/jhea.9.7168

This work is brought to you for free and open access by the Institute of Clinical Bioethics (ICB) at Saint Joseph's University, Philadelphia, PA, U.S.A. It has been accepted for inclusion in The Journal of Healthcare Ethics \& Administration by the editorial board and an authorized administrator of the JHEA. For more information, please contact support@jheaonline.org 


\section{THE JOURNAL OF HEALTHCARE ETHICS \& ADMINISTRATION \\ Vol. 6 | No. 1 (Spring/Summer 2020)}

There are doctors who are poor too.

There are doctors who have loans too.

There are doctors who do not own houses too.

There are doctors who do not have cars too.

There are doctors with personal and financial commitments too.

There are doctors who need guidance too.

There are doctors who are not CoVID specialists too.

There are doctors with health risks too.

The real frontline staff in a hospital are the staff nurses, technicians, housekeeping, security guards, ambulance drivers, ward attenders, junior and senior resident doctors. A hospital is nothing without them. The least one can do is support them morally and financially in times of crisis. Decisions that you make in the board rooms with the hospital administrators only reflects on how much you are willing to stand up for your team, YOUR PEOPLE during this crisis. We junior members in the medical fraternity are all going to remember what you do for us now.

Be a role model.

If the hospital administration is running short of funds, they need to ask help from the government, look at their funding sources and recheck their contingency plans if any. We are not qualified to opine on this unless one is a part of the administration or is the owner of the hospital, we are trained only to save lives. We should not be asked for any contributions to run the hospitalneither ideas nor money.

Right now we need to read and research, develop infection control and treatment protocols, conduct more online interdepartmental meetings, gear up our frontline team members and most importantly take care of ourselves and our families. Our time and attention should be completely on that. The frontline should not bear the brunt, they have CoVID right at their face, on their hands. Nobody else is expected to understand this better than you.

A sincere request from,

A Junior Doctor who got into this sacred profession inspired by someone like you.

\section{ACKNOWLEDGMENT:}

This letter is dedicated to all residents of all hospitals across India who are the frontline and the most important part of the CoVID-19 pandemic management. 